\title{
Collaborative Action Research in the Context of Developmental Work Research: A Methodological Approach for Science Teachers' Professional Development
}

\author{
Panagiotis Piliouras ${ }^{1}$, Dimitris Lathouris ${ }^{1}$, Katerina Plakitsi ${ }^{2,}{ }^{*} \&$ Liana Stylianou $^{3}$ \\ ${ }^{1}$ Ministry of Education, Greece \\ ${ }^{2}$ Department of Early Childhood Education, School of Education, University of Ioannina, Greece \\ ${ }^{3}$ Environmental Education Centre of Naoussa, Greece \\ *Correspondence: Department of Early Childhood Education, School of Education, University of Ioannina, Greece. \\ E-mail: kplakits@cc.uoi.gr
}

Received: May 19, 2015

Accepted: June 16, $2015 \quad$ Online Published: December 15, 2015

doi:10.5430/wje.v5n6p74

URL: http://dx.doi.org/10.5430/wje.v5n6p74

\begin{abstract}
The paper refers to the theoretical establishment and brief presentation of collaborative action research with the characteristics of "developmental work research" as an effective methodological approach so that science teachers develop themselves professionally. A specific case study is presented, in which we aimed to transform the basically monologic discourse of teacher-pupil interactions to a more collaborative, investigative one by engaging teachers-researchers in the analysis of their own discourse practices. The engagement of teachers-researchers in collaborative action research and, more specifically, in the analysis of their own discourse and the way they worked with, collaborated with and guided their pupils in science lessons proved to be an educationally creative, effective process in their training. The study and analysis of the data, which took place after the active participation of the teachers-researchers, showed that that teachers and pupils can develop desired, collaborative, dialogic skills and meta-skills on the basis of utilizing certain strategies. The most significant strategy, which was utilized during collaborative action research, was discourse analysis not only as a study tool of social school reality but also as a training, reflective, meta-didactic tool.
\end{abstract}

Keywords: Collaborative action research; Developmental work research; Science teachers' professional development

\section{Introduction}

Engeström (1999) has proposed "developmental work research" as an interventionist, research methodology in the context of action theory and sociocultural approaches. This research approach is participatory, evolutionary, holistic and developmental. The paper refers to the theoretical establishment and support with the empirical data of collaborative action research with the characteristics of developmental work research as an effective methodological approach to science teachers' professional development. Classic collaborative action researches are creatively completed when enriched with the principles of sociocultural approaches. Based on the assertion that training/professional development involves transformation through participation in collective/collaborative endeavors (Rogoff, 2003), this methodological approach promotes collaborative inquiry (the basic orientation of sociocultural approaches) not only in a pedagogic, but also, a research level: teachers as researchers.

In the theoretical part of the paper, we discuss the shift from exclusively individual learning to collaborative, inquiring learning derived from sociocultural orientations not only in a teaching-learning level but also a research teaching-learning practices level. We document why action research as a research methodology in science education is important and how it can be enhanced with the characteristics of "developmental work research" in order to be used as an effective professional development strategy for science teachers. In the research part of the paper, a case study is presented, in which, by involving teachers in collaborative action research and by engaging teachers-researchers in the analysis of their own discourse practices, we aimed to transform teacher-pupil interactions into more collaborative, exploratory ones. 


\section{Sociocultural Approaches in the Foreground: From Exclusively Individual Learning to Collaborative, Inquiring Learning}

In recent years, there has been a shift from views supporting that learning is an absolutely individual process to views asserting that learning contents social and cultural processes (e.g. Saxe, 2002; Rogoff, 2003). Representatives of various sociocultural views, intending to "enlighten" the collaborative and inquiry nature of learning procedure, refer to learning as "a peripheral participation to a community of practice" (Lave \& Wenger, 1991), "a gradually improved participation in an interactive system" (Greeno, 1997), "the reorganizing of an activity" (Cobb,1998), "the result of participation in communities" (Rogoff, 2003).

A basic assertion of sociocultural approaches is the recognition of the social nature of the cognitive process (e.g. Vygotsky, 1962). A second assertion is that learning in the context of sociocultural approaches is regarded as the transformation of the participation in collaborative learning activities (Rogoff, 2003). Another assertion is the dominant position and determinant role that language and verbal interaction hold in the transformation and appropriation of knowledge (Wells, 1999).

The above lead as to support that as we pursue the creation of "learning communities" (Rogoff, Matusov \& White, 1996) or "communities of practices" (Lave \& Wenger, 1991) in a classroom level, we are also called upon the creation of "communities of researchers" in a research level.

\section{Collaborative Action Research: The Classics}

Action research is a functional way for one to examine his practice, intending to test it in relation to the standard pursued and, after that, to improve it (McNiff, 1995). In recent years, there are definitions that elicit the collaborative and collective nature of the action research. According to Heron (1996), a collaborative action research/ inquiry is a form of participating research, which takes place jointly with teachers and researchers. Action research can be described as a summation of research methodologies, which simultaneously pursue action (shift) and research (understanding). Lately, particular emphasis has been given to approaches that adopt collaborative action research as a strategy of professional development of teachers (e.g. Altrichter, Posch \& Somekh, 1993; Feldman, \& Minstrell, 2000). By studying these papers, we come to the conclusion that when action research satisfies basic requirements like having a participating and collaborative character, congruously interweaving theory with action, being reflective and critical, then it presents a sequence of desired results as:

- Teachers are more prepared to apply effective teaching practices.

- There is development of their skills in applying teaching strategies.

- Their interest about educational process is replenished.

- Their interest about awareness in teaching and learning issues increases.

- Their self-awareness increases.

The use of action research is well documented in the scope of research and teaching science. It has been utilized with positive results in three sections of science education:

- As a basic training tool in teachers' education and their professional development (e.g. Wells, 2002).

- As a research methodological tool for teaching and learning science (e.g. Feldman \& Minstrell, 2000).

- As a methodological approach for the development and application of curriculums on thematic topics.

\section{Collaborative Action Research with the Features of Developmental Work Research}

Sociocultural approaches and especially the activity theory can further enrich the researches oriented to action and as Edwards (2000) mentions, can complete the directions of collaborative action research creatively. As Kuuti (1999) supports "activity theory is interventionist as far as its methological approach is concerned". Adopting the view of people as the creators of their own contexts of activity, it aims to transform contexts of practice so that people are not faced merely as objects or dependent parts but regain their role as creators". Shotter (1993, p.111) asserts that it is, basically, sociocultural approaches that turned our attention to the study of the way in which people (in our case teachers and learners), through participating in social activities, gradually transform the conditions of the activities they take part in. Simultaneously, it is them which give emphasis to the study of the relation between action on one hand (in our case learning activities in science) and cultural, institutional and historical situations, on the other hand, in which they take place (Wertsch, del Rio \& Alvarez, 1996, p.11). 
The traditional action researches do not take into consideration the historical-cultural nature of the research process. Engeström (1999) has supported an interventionist research methodology in the context of the activity theory, which, as he implies, should aim at the mediation, recording and analysis of the cycles of extensive knowledge in local systems of activities. This research approach which Engeström calls developmental work research is participatory, evolutionary, contextual, holistic and developmental. A collaborative action research with the features of developmental work research includes the following actions:

- The first action is the study, critical examination or rejection of some views of current practices.

- The second action is the analysis of the situation. This analysis includes the analysis of the words and actions of the activity that is going to be transformed, with the aim to detect the causes ("why") and explanatory mechanisms. a) A type of analysis is a historical-genetic one, where the explanation of the situation on the basis of its origins and its evolution is sought. b) Another type of analysis is an actual-empirical one, where the explanation of the situation, creating an image for its internal, systemic relationships, is sought.

- The third action is modelling, that is to say the creation of a certain model, which explains the new idea and (may) offer(s) a solution to the problematic situation.

- The forth action is the examination of the model, that is the testing of its function and the experimentation on it, with the aim to test its dynamics, its potentials and its weaknesses.

- The fifth and last action is the application of the model, making its specification through its practical applications, its enrichment and dynamic expansion. A methodological approach of such a direction is essential to be explorative, participatory, collaborative and reflective.

Subsequently, a certain case of a study is presented, in which the developmental work research was used as a methodological tool for science teachers' development/training.

\section{An Effort to Transform Teacher-Students Dialogues to More Collaborative Investigative Forms of Teaching Science}

The research, the collaborative action research with the features of developmental work research, took place. Eight teachers in $5^{\text {th }}$ and $6^{\text {th }}$ grade of Primary School in one private and seven public schools of Athens as teacher-researcher participated in the research.

The aim of the research was the study and the gradual transformation of teachers-pupils dialogues, so that more collaborative, investigative conditions in science are ensured within the classrooms of the teachers-researchers who took part in the action research. More certainly, we, that is the researchers and the teachers-researchers, utilized strategies which aimed at the progressive change of the nature and type of the teacher-pupils' dialogues that took place within the eight classrooms while teaching science and corresponding practices. This endeavor aimed to achieve a critical and reflective approach, focusing not only on examining the discourse and practices of teachers-researchers and pupils but also on gradually transforming those which opposed to the purposes that had been set in the context of the collaborative action research.

A basic assumption of this research, coming from sociocultural views, was that the communicative actions of a teacher contribute, decisively, to forming pupils' views about the nature of science, its learning and teaching, its language, the purposes of them getting educated about science and, finally, the kind of learning which relates to science and takes place there.

The basic question studied was:

Can the use and development of discourse analysis tools by teachers-researchers and the designing of appropriate strategies based on the conclusions stemming from these analyses lead to the gradual transformation of the nature and type of teachers-researchers' discourse and how, so that they are characterized by more collaborative investigative features?

The research endeavor focused on the materialization of an oriented to discourse analysis admission that critical reflection on how we make a meaning can give us the chance to examine and seek possible alternative ways of communicative actions during science lesson.

Adopting a collaborative action research approach with the features of developmental work research and the use of discourse analysis tools mainly coming from sociocultural educational tradition, we tried, by engaging 
teachers-researchers with the analysis of their own discourse practices actively, to transform the basically monologic discourse of teacher-pupil interactions to a more collaborative and investigative one.

Below the sub-actions which were utilized based on Engeström's suggestion about a research approach with the features of developmental work research, are presented:

Action1: Study of research literature about teacher-pupil interactions

Action 2: How do we talk in our classroom?

Action 3: How could we talk in our classroom? Defining desired discourse practices

Action 4: Examination of emerging transformed discourse practices and their gradual standardization.

A brief presentation of the sub-actions follows:

\subsection{Action 1: Study of Research Literature}

In the context of this action, we carried out a review of the research literature about teacher-pupils communicative actions during science lesson. The study of research literature resulted that a basic barrier about the creation of more collaborative investigative conditions in a classroom of science is discourse practices which are developed between teachers and pupils (e.g. Mortimer \& Scott, 2003). Therefore, we were led to the view that the transformation of not desired, monologic discourses between teachers and pupils could perhaps be achieved with a collaborative action research, which would actively engage teachers-researchers in research process. Moreover, the study of research literature gave us enough discourse analysis tools. These tools were transformed and utilized in our research. In a first level, they were used to familiarize/train the teachers-researchers and in a second (post-didactic) level, to examine our practices critically and to aim at the transformation of learning activities.

\subsection{Action 2: How Do We Talk in Our Classroom?}

In this action, teachers-pupils' dialogues in 8 classrooms were recorded, then transcribed and, finally, selected extracts were analyzed by the teachers-researchers in collaboration with the researcher. The tools of analysis, mainly, came from sociocultural approaches. The teachers-researchers were informed about the way of analysis and the theoretical framework of sociocultural approaches which the whole endeavor was based on.

The sub-questions for this sub-action (which concerns the initial stage of research) were the following:

- Were the desired collaborative investigative features presented during science lesson, in which pupils worked in groups?

- What collaborative strategies and discourse strategies did the teachers follow? To what extent could they create collaborative investigative conditions?

The study of the data of the second sub-action, which concerned the examination of the teachers' discourses themselves, elicited difficulties and problems to our intention of creating collaborative investigative conditions in science classrooms. Totally, monologic rather than collaborative investigative features prevailed in most classrooms.

The basic problems/barriers (as far as teachers-researchers are concerned) about the formation of more collaborative investigative conditions in science lesson that we found studying and analyzing teacher-pupil dialogues but also other research data (observations, videotaped teaching) were the followings:

- Teachers-researchers did not take advantage nor utilized pupils' views and suggestions.

- Teachers-researchers did not have skills to the desired extent in order to create collaborative learning environment.

- Teachers-researchers did not know about or were not familiarized with collaborative discourse strategies.

- Teachers-researchers did not bridge pupils' daily knowledge with scientific knowledge

- Teachers-researchers through their discourse, against their will, communicated/created not desired meanings about the nature of science, learning and teaching, language, science teaching aims and activities

- Exclusive adherence to school textbooks

We moved on to Engestrom's suggestion and we analyzed the whole situation and the above problems in two dimensions, historical-genetic and current-empirical. The analysis helped us to understand that it was not teachers' weakness to create collaborative investigative conditions due to the fact that they were not trained or informed but mainly the historically determined participation of teachers-researchers during their teaching life - at all levels of 
their education - in monologic, transferrable practices. Therefore, they did not have the essential collaborative repertoires to work to the desired direction.

\subsection{Action 3: How Could We Talk in Our Classroom? Defining Desired Discourse Practices}

Although teachers-researchers were gradually informed about the features of collaborative investigative environments, (e.g. inquiry as an organizational principle of learning activities, guided participation, and use of discourse strategies which would offer scaffolding during learning process) they could not transform this training material to teaching repertoires automatically and implement it in their everyday teaching practices.

So we considered that it is essential to discuss broadly about these problems (in relation with the collaborative investigative framework, which we intended to create) seek, define and agree on strategies (mainly the desired discourse practices), which could help for the creation of more desired collaborative conditions. To face each of those issues that were mentioned in the previous sub-unit, we formed strategies and micro-strategies and we agreed to aim at their utilization so as to create the collaborative investigative conditions. The following table (1) concerns the decisions taken about the utilization of the strategies which would improve the fact that teachers-researchers were not familiarized with the desired collaborative discourse strategies.

Table 1. Teachers-Researchers Gradual Familiarization with Collaborative Discourse Strategies

The aim of strategies' application Strategies

- Familiarization with questions which offer scaffolding to pupils

The gradual familiarization of teachers with the desired for our framework collaborative inquiry discourse repertoire. and groups, facilitate participation and create the conditions for collaborative inquiry of views, questions, problems.

- Creative utilization of a triadic dialogue model.

- Awareness about the nature of a teacher's interventions in communicative interactions level.

We analyzed the desired strategies into the following micro-strategies and we agreed with teachers-researchers to try to utilize them:

- Focus pupils' interest on an intended version of activity.

- Support pupils' activity while those try to achieve a certain target, while enforcing and guiding their actions.

- Elicit significant elements of activity.

- Work as a model of the skills and practices which pupils are to be familiarized with.

- Promote scientific knowledge selecting pupils' answers appropriately.

- Ensure, through guiding every time, the coordination and coherence of learning activities.

- Review opinions which were expressed and points which were adopted.

- Guide appropriately to fix communication among the members of a group or among the groups in a classroom.

- Explicate and give hints for activities which take place.

- Engage all members of a group and all groups in inquiry.

- Initiate scientific words at the right moment.

- Make questions which promote inquiry of points, views, and meanings.

- Avoid questions which demand that pupils guess the desirable answer.

- Make views available for all pupils in classroom.

- Ask pupils or groups to write down their views and support them with arguments.

\subsection{Action 4: Examination of Transformed Discourse Practices and Their Gradual Standardization}

In this action, which concerns the last stage of our research, we continue teachers-pupils dialogues analysis, to see the extent to which they were transformed to more collaborative investigative research, after teachers-researchers engagement in the three previous sub-actions. 
Totally, in the last stage of our research, after the study and analysis of the dialogues on the basis of the analysis of the frameworks we took advantage of, we resulted in the fact that teachers-researchers created, to a satisfactory extent, desired collaborative investigative conditions. They were gradually familiarized with essential collaborative and dialogic skills - started using micro-strategies which were agreed (as those of the above table) more and more often - which motivate pupils to participate, exchange views and arguments, to engage themselves in collaborative inquiry. They usually avoided to use only close questions and intended to create desired, for our framework, meanings about the nature of science. As far as the nature of teaching is concerned, they worked more as facilitators rather than distributors of knowledge. They guided the learning process appropriately and created the desired meaning about the role of language and the targets of science.

Completing this action, we went on the standardization of desired practices.

\section{Discussing on All Actions}

In conclusion, the engagement of teachers-researchers in collaborative action research with the characteristics of developmental work research and, more specifically, in the analysis of their own discourse and the way they worked, collaborated and guided their pupils in science lessons proved to be an educationally creative and effective process in training.

The study and analysis of the data, which took place thanks to the active participation of the teachers-researchers, showed that before being familiarized but also before developing the theoretical and practical background (the initial stage of research), they did not have, to a satisfactory extent, the essential skills to form a collaborative investigative environment. Of course, this had to do, to a significant extent, with the history of each teacher and his/her participation in monologic discourse and practices during his/her life. Most teachers, with their communicative contributions and practices, formed a monophonic imperative discourse, a non collaborative investigative environment.

Gradually, during our research, the learning environments in the classrooms of the teachers-researchers were transformed into more collaborative investigative conditions. The analysis and study of the data from the intermediate and final stage of the research showed that the teachers and pupils can develop desired collaborative and dialogic skills and meta-skills on the basis of utilizing certain strategies. The most significant strategy which was utilized during collaborative action research was discourse analysis, not only as a study tool of social school reality but also as training, reflective and meta-didactic tool.

The desired collaborative investigative environment is not created only when a researcher and teachers-researchers are informed about some desired practices. Active participation in a research/meta-didactic level is essential as a crucial and complementary parameter of their experiential training.

\section{Epilogue}

According to Aikenhead (2003): "The most promising challenging guide line for future research is action research that has the teachers themselves' attitude as a starting point", while Carr and Kemmis (1986) support that the educational research is not only a scope of action for the 'experts' and that teachers' professional development requires the adoption of a research attitude towards their practices. Stenhouse (1975) argued that "... it is teachers who will eventually change the "world" of their class by trying to understand it", while Schön (1991) considers that practice as a research (practice-as-inquiry) can illuminate and transform business practices. That is why we support the value of collaborative action research with the characteristics of developmental work research as a methodological tool for active teachers' training and students' education.

The combined and active participation of teachers, both in a teaching and research- meta-didactic level, can have educational, practical - pedagogical, meta-didactic-reflective contribution, as:

- Their expertise in didactic issues is improved and they gradually develop a deeper understanding for all the parameters of the learning process

- They become informed about collaborative inquiry but also the transforming nature of the learning process, become more open to new ideas which they often adopt and try to transform them according to pupils' needs.

- They gain more confidence about decisions they make, take initiatives and contribute to the formation of the educational policy of their school and more broadly. 


\section{References}

Aikenhead, G. (2003). Review of Research on Humanistic Perspectives in Science Curricula. A paper presented at the European Science Education Research Association (ESERA) Conference, Noordwijkerhout, The Netherlands, August 19-23, 2003.

Altrichter, H., Posch, P., \& Somekh, B. (1993) Teachers investigate their work: an introduction to the methods of action research. London: Routledge.

Carr, W., \& Kemmis, S. (1986). Becoming Critical: Education, Knowledge and Action Research. London: Falmer Press.

Cobb, P. (1998). Learning from distributed theories of intelligence. Mind, Culture, and Activity, 5(3), 187-204. http://dx.doi.org/10.1207/s15327884mca0503_4

Edwards, A. (2000). Looking at Action Research through the Lenses of Sociocultural Psychology and Activity Theory. Educational Action Research, 8(1), 195-204. http://dx.doi.org/10.1080/09650790000200104

Engeström, Y. (1999). Innovative Learning in Work Teams: Analyzing Cycles of Knowledge Creation in Practice. In: Y. Engestrom, R. Miettinen and R. Punamaki, Eds., Perspectives on Activity Theory (p.p. 377-404). Cambridge: Cambridge University Press.

Feldman, A., \& Minstrell, J. (2000). Action research as a research methodology for the study of the teaching and learning of science. In E. Kelly \& R. Lesh (Eds.): "Handbook of research design in mathematics and science education." Mahwah, NJ: Lawrence Erlbaum Associates.

Greeno J. G. (1997). Response: On claims that answer the wrong questions. Educational Researcher, 26, 5-17. http://dx.doi.org/10.2307/1176867

Heron, J. (1996). Co-operative Inquiry: Research into the Human Condition. Sage Publications.

Kuutti, K. (1999). Activity theory, transformation of work, and information systems design. In Y. Engeström, R. Miettinen, \& R.-L. Punamäki (Eds.), Perspectives on activity theory (pp. 360-376). Cambridge, England: Cambridge University Press.

Lave, J., \& Wenger, E. (1991). Situated Learning: Legitimate peripheral participation. New York: Cambridge University Press. http://dx.doi.org/10.1017/CBO9780511815355

McNiff, J. (1995). Teaching as learning: An action research approach. London: Routledge.

Mortimer, E., \& Wertsch J. (2003). The Architecture and Dynamics of Intersubjectivity in Science Classrooms. Mind, Culture, and Activity, 10(3), 230-244. http://dx.doi.org/10.1207/s15327884mca1003_5

Rogoff, B. (2003). The cultural nature of human development. New York: Oxford University Press.

Rogoff, B., Matusov, E. \& White, C. (1996). Models of teaching and learning: Participation in a community of learners. In D. Olson \& N. Torrance (Eds.), Handbook of education and human development: New models of learning, teaching, and schooling. London: Basil Blackwell.

Saxe, B. G. (2002). Children's Developing Mathematics in Collective Practices: A Framework for Analysis. Journal of the Learning Sciences, 11(2 \& 3), 275-300. http://dx.doi.org/10.1080/10508406.2002.9672140

Schön, D. A. (1991). The Reflective Turn: Case Studies In and On Educational Practice. New York: Teachers Press, Columbia University.

Shotter, J. (1993). Cultural Politics of Everyday Life. Buckingham: Open University Press.

Stenhouse, L. (1975). An introduction to curriculum research and development. London: Heinemann.

Vygotsky, L.S. (1962). Thought and Language. Cambridge. Massachusetts: MIT Press. http://dx.doi.org/10.1037/11193-000

Wells, G. (1999). Dialogic Inquiry. Toward a Sociocultural Practice and Theory in Education. Cambridge University Press.

Wells, G. (2002). Inquiry as an orientation for learning, teaching and Teacher education. In G. Wells \& G. Claxton (Eds.), Learning for Life in the $21^{\text {st }}$ Century (p.p. 197-210). Blackwell Publishing. http://dx.doi.org/10.1017/cbo9780511605895

Wertsch, J., del Rio, P., \& Alvarez, A. (1996). Sociocultural Studies; history, action and mediation. In J. Wertsch, P., del Rio, \& Alvarez. A. (Eds.), Sociocultural Studies of Mind. Cambridge: Cambridge University Press. 